\title{
Interleukin 30 Measurement
}

National Cancer Institute

\section{Source}

National Cancer Institute. Interleukin 30 Measurement. NCI Thesaurus. Code C74828.

The determination of the amount of interleukin 30 present in a sample. 